\title{
Foreign Trade and Economic Growth In Nigeria An Empirical Analysis
}

\author{
${ }^{1}$ Atoyebi Kehinde .O., ${ }^{2}$ Adekunjo Felix .O., ${ }^{3}$ Edun Olufemi (Ph.D), \\ ${ }^{4}$ Kadiri Kayode I. \\ ${ }^{1,2,3,4}$ Department of Economics, Lagos State University, Ojo, Lagos
}

\begin{abstract}
This study empirically examine the impact of international trade on economic growth in Nigeria from 1970-2010. Being a time series data, to avoid spurious regression result, the first step was to test for stationary of the data by using Phillips Peron unit root test. Then Johansen (1988) technique was used to establish if the non-stationary variable are cointegrated. The result of stationary and normality test reveals that the model is fairly well specified and could be used for policy analysis. Empirical investigations reveal that three variables are statistically significant at 5\% and these variables are export, foreign direct investment and exchange rate and they are positively related to real GDP while other variables such as import, inflation rate, openness exert a negative influence on real GDP. The study demonstrates that increase participation in global trade helps Nigeria to reap static and dynamic benefit of international trade despite non conformity of the coefficient of the openness. Both international trade volume and trade structure towards high technology export result in positively effect on Nigeria economy. We therefore recommend that the government should design appropriate strategy by diversifying the economy through export promotion, stimulating foreign direct investment and exchange rate stability in order to boost productivity of Nigeria economy by raising the standard of living of the citizens.
\end{abstract}

Keywords: International t Trade, Economic Growth, Diversification and Openness.

\section{Introduction}

Foreign trade can been defined as trade across the frontiers that is with the rest of the world, it has been argued that, it plays a prominent role in promoting economic growth and productivity in particular, and debate have been ongoing since several decades ago. Historical validation has revealed that internationally active countries tend to be more productive than countries which only produce for the domestic market. As a result of liberalization and globalisation a country's economy has become much more closely associated with external factors such as openness. Against this background, conducting a study on the effects of international trade on economic growth is imperative in this globalise era. It helps policymakers to marshal appropriate policies by determining the source of productivity growth with respect to international trade.

Since the introduction of economic reforms and the adoption of outward oriented strategies in Nigeria, Nigeria economy have experienced dramatic growth. Additionally, Nigeria participation in international trade has contributed tremendously in productivity of domestic industries and advancement of technology. Therefore, research on how international trade contributed Nigeria's economy growth can serve has a distinguishing case study revealing a latecomer catches up with forerunners by increasing his participation on the global stage.

This study begins with literature review from the perspective of international trade effect on economic growth in section 2 .

In section 3, stylized facts are discussed respectively. Model specification, estimation and interpretation of result are discussed in section 4.

Section 5 presents summary, conclusion and recommendation according to the model constructed in this research.

\section{Review Of Selected Existing Literature}

Detailed and historical validation has proved that international trade affects economic growth positively by stimulating capital accumulation, industrialization, technological progress and institutional development specifically increased imports of capital and intermediate products, which are not available in the domestic market may induce the productivity of the manufacturing sector (Lec, 1995).

More active participation in the international market by promoting exports will lead to competition and trade improvements in terms of productivity (Wagner, 2007).

Before the 1960s, research in trade effects was actually limited to a few specific countries, with the development of econometrics, however, many complicated methods based on a mathematical model were introduced to analyse the impact between trade and economic growth. So far, opinion has been divided into two categories. One focuses on the causality relationship between international trade and economic growth to 
examine whether economic growth is propelled by international trade or the other way round. The other mainly discusses the contribution of foreign trade to economic growth.

The OECD (2003) studies the impact of trade on the average income per population. The result revealed that elasticity of international trade was 0.2 which was statically significant Maizel's (1963) investigated the impact of international trade on economic growth using a rank correlation analysis among developed countries. The results of the study showed a positive relationship between international trade and economic growth.

Kavousssi (1984), after studying 73 middle and low income developing countries found out that the higher rates of economic growth was strongly correlated with higher rates of export growth. He revealed that there exist a positive correlation between exports and economic growth for both middle and low income countries but the effects tend to diminish according to the level of development. Balassa (1986) and Dollar (1992) argued that outward oriented developing economies achieve more rapid growth than inward oriented developing ones. Sachs and Warner (1995) construct a policy index to analyse economic growth rate and found that the average growth rate in the period after trade liberalization is significantly higher than in the period before liberalization.

Baldwin (2003) demonstrated persuasively that countries with few trade restriction achieve more rapid economic growth than countries with more restricted policies. As poverty will be reduced more quickly through faster growth, poor countries could use trade liberalization as a policy tool. Trade liberalization reduces relative price distributions and allows those activities with a comparative advantage to expand and consequently foster economic growth. Poor countries tend to engage in labour - intensive activities due to an over abundance labour supply.

Thus the removal of trade openness measures seem to be positively associated with GDP growth - the more open the economy, the slower the growth rate. On the other hand, trade restrictions or barriers are associated with reduced growth rates and social welfare and countries with higher degree of protectionism, on average, tend to grow at a much slower pace than countries with fewer trade restrictions. This is because tariffs reflects additional direct cost that producers have to absorb, which could reduce output and growth.

Oyejide (1997) also points out the impact of restrictive measures was to produce a large anti-export bias in the African countries. More specifically, restrictions on imports translate effectively into a tax on exports by making import substitution effectively more profitable they increase barriers in these countries by promoting intense economic activity via employment and income to many impoverished people.

Ann Harrison's (1991) study makes a synthesis of previous empirical studies between openness and the rate of GDP growth comparing the results from cross section and panel estimations while controlling for country effects. The study concluded that on the whole, correlations across openness measure seem to be positively associated with GDP growth - the more open the economy, the higher the growth rate or the more protected the local economy.

Khan and Zahler (1985) assert that trade can promote growth from the supply side, but if the balance of payments cost reduces the availability of imported inputs which enter the product of exports, thus forcing exporters to use expensive imports of doubtful quality.

In a 1998 study of the role of trade and trade policy in achieving sustained long term growth in African countries, Dani Rodrik (1998) concluded that high levels of trade restriction have been an important obstacle to export performance and growth. He contends that the reduction of these restrictions can be expected to result in significantly improved trade perofamcance in the region.

Fraikel and Roman (1999) and Irwin and Tevio (2002) in their separate and independent studies suggested that countries that are more open to trade tends to experience higher growth rates and per capital in income than closed economy Klanow and Rodriguez - Clare (1997) need used general equilibrium model to establish that the greater number of intermediate input combination results in productivity gain and higher output, despite using same capital and labour input which exhibit increasing return to scale.

Ghezakos (1973) examines the effect of export instability on economic growth in 18 developed and 50 less developed countries separately. The growth rate of export proceeds has a positive effect in explaining the growth rate of real per capita income. Michaely (1977) focuses attention on correction between the rate of growth of export and GNP. Michaely finds that the correlation between rates of growth of the economy is particularly strong among the countries with successful growth experience. Balassa (1978) in his study of eleven countries that have an established industrial base discovers that the positive correlation between export growth and the GDP growth will provide indication of the total effects of exports on economic growth. Shuchin Yang of the World Bank Development institute also maintains that exports are the major dynamic factor in determining the level of general economic activity in most primary exporting countries. He also argues that if the developing countries do not develop their export, it might mean slow economic growth (Shuchin 1979). Similarly, Bairam (1988) estimates the model for a large sample of developed countries and arrived at the conclusion that the growth performance of a country is a function of the values of its income elasticity of both export and imports. In the same vein, Perraton (1990) solves the model for 59 developing countries for the period between 1970 and 
1984 and report that the model provides a good fit. For almost one half of the sampled countries. This study also suggests that a country growth performance depends on income elasticity of both exports and imports.

Lin and Li (2002) examined the contribution of feign trade to China's economic growth and found that the previous studies on this subject underestimated the contribution of exports to GDP growth by over looking the indirect impacts of exports on domestic consumption, investment, government expenditures and imports. They proposed a new estimation method and found that a ten percent increase in exports resulted in a one percent increase in GDP in the 1990s in China, when both direct and indirect contributions are considered. In another study, Wah (2004) reported for the past four decades (1961-2000), the Malaysian economy grew at an impressive average rate of $6.8 \%$ per annum. The rapid growth was attributed, in part, to the tremendous success in the export-oriented industrialization policy.

In Nigeria some authors had examined the performance of foreign trade and economic growth. For instance, Oyejide (1974), using Nigeria, as a laboratory test ground that an increase in export proceeds could lead to an expansion.

Ogbokor (2001), investigated the macroeconomic impact of oil exports of oil exports on the economy of Nigeria. Utilizing the popular OLS technique, he observed that economic growth reacted in a used in the study. He also found that $10 \%$ increase in oil exports would lead to $5.2 \%$ jump in economic growth. He concluded that export-oriented strategies should be given a more practical support. Oviemuno (2007), looks at international trade as an engine of growth in developing countries taking Nigeria (1960-2003) as case study, he uses four important variables which are export/import, inflation and exchange rate.

The results shows that Nigeria exports value does not act as an engine of growth in Nigeria.

\subsection{TRADE AS ENGINE OF GROWTH THEORETICAL REVIEW}

The origins of trade can be traced to the absolute and comparative advantage as well as Hecksher Ohlin theories (Jayme, 2001). The theory of absolute advantage was formulated by Adam Smith in his famous book title "Inquiry into the nature and the wealth of Nation" 1776. The theory emanated due to the demise of mercantilism. Smith argued that with free trade each nation could specialize in the production of those commodities in which it could produce more efficiently than other nations and import those commodities it could not produce efficiently.

According to him, the international specialization of factors in production would result in increase in the world output. Thus this specialization makes goods available to all nations.

\subsection{COMPARATIVE ADVANTAGE THEORY}

This theory was propounded David Ricardo. The theory assumed the existence of two countries, two commodities and one factors of production. To him a country export the commodity whose comparative advantage lower and import commodity whose comparative cost is higher. The theory also assumed that the level of technology is fixed for both nations and that trades is balanced and rolls out the flow of money between nations. However, the theory is based on the labour theory of values which states that the price of the values of a commodity is equal to the labour time going into the production process. Labour is used in a fixed proportion in the production of all commodity. But the assumptions underlying is quite unrealistic because labour can be subdivided into skilled, semiskilled and unskilled labour and there are other factors of production.

Despite the limitations, comparative cost advantage cannot be discarded because its application is relevant in explaining the concept of opportunity cost in the modern theory of trade.

\subsection{HECKSHER-OHLIN TRADE THEORY}

The theory focuses on the differences in relative factor endowments and factor prices between nations on the assumption of equal technology and tastes. The Model was based on two main propositions; namely; a country will specialize in the production and export of commodity whose production requires intensive use of abundant resources.

Secondly, countries differs in factor endowment. Some countries are capital intensive while some are labour intensive. He identified the different in pre-trade product prices between nations as the immediate basis of trade, the prices depends on production possibility curve (supply side) as well as the taste and preference (demand side). But the production possibility curve depends on factor endowment and technology. To him, a nation should produce and export a product for which abundant resources is used be it capital or labour. The model suggests that developing countries are labour abundant and therefore they should concentrate in the production of primary product such as agricultural product and they should import capital intensive product i.e manufactured goods from the developed countries. The model also assumes two countries, two commodities and two factor and that two factors inputs labour and capital are homogenous. The production function is assumed to exhibit constant return to scale.

However, the theory is not free from criticism and this because factors inputs are not identical in quality and cannot be measured in homogenous units. Also factor endowments differs in quality and variety. Relative factor 
prices reflects differences in relative factor endowment- supply therefore outweigh demand in the determination of factor prices.

Despite this criticism, trade increase the total world output. All countries gain from trade and it also enables countries to secure capital and consumption of goods from the rest of the world.

\subsection{THEORIES OF ECONOMIC GROWTH}

Economic growth is best defined as a long term expansion of productive potential of the economy. Trend growth is the smooth path of long run national output i.e it requires a long run series of macroeconomic data which could be twenty years or more. The trend of growth could be expanded by raising capital investment spending as a share of national income as well as the size of both capital inputs and labour supply, labour force and the technological advancement. There are different school of thought that have discussed the causes of growth and development and they are:

\subsubsection{NEO-CLASSICAL GROWTH}

This was first propounded by Robert Solow over 40 years ago. The model believes that a sustained increase in capital investments increased the growth rate only temporarily, because the ratio of capital to labour goes up. The marginal product of additional units is assumed to decline and thus an economy eventually moves back to a long term growth-path with the real GDP growing at the same rate as the growth of the workforce plus factor to reflect improving productivity. Neo-classical economists who subscribe to the Solow model believes that to raise an economy long term trend rate of growth requires an increase in labour supply and also a higher level of productivity of labour and capital.

Differences in the rate of technological change between countries are said to explain much of the variation in growth rates. The neo-classical models treats productivity improvements as an exogenous variable which means that productivity improvements are assumed to be independent of the amount of capital investment.

\subsubsection{ENDOGENOUS GROWTH THEORY}

To them, they believe that improvements in productivity can be attributed directly to a faster pace of innovation and extral investment in human capital. They stress the need for government and private sector institutions to encourage innovation and provide incentives for individual and business to be inventive. There is also central role of the accumulation of knowledge as a determinant of growth i.e knowledge industries such as telecommunication, electronics, software or biotechnology are becoming increasingly important in developed countries. The proponent of endogenous growth theory believes that there are positive externalities to be exploited from the development of a high value added knowledge economy which is able to developed and maintain a competitive advantage infact growth within the global economy. They are of the opinion that the rate of technological progress should not be taken as a constant in a growth model- government policies can permanently raise a country growth rate if they lead to move intense competition in markets and help to stimulate product and process innovation. That they are increasing returns to scale from new capital investment and also private sector investment is a key source of technical progress and that investment in human capital is an essential ingredient of long term growth.

\subsubsection{HARROD - DOMAR GROWTH MODEL}

Harrod-Domar opined that economic growth is achieved when more investment leads to more growth. They theory is based on linear production function with output given by capital stock $(\mathrm{K})$ tines a constant. Investment according to the theory generates income and also augments the productive capacity of the economy by increasing the capital stock. In as much as there is net investment, real income and output continue to expend. And, for full employment equilibrium level of income and output to be maintained, both real income and output should expand at the same rate with the productive capacity of the capital stock.

The theory maintained that for the economy to maintain a full employment, in the long run, net investment must increase continuously as well as growth in the real income at a rate sufficient enough to maintain full capacity use of a growing stock of capital. This implies that a net addition to the capital stock in the form of new investment will go along way to increase the flow of national income. From the theory, the national savings ratio is assumed to be a fixed proportions of national output and that total investment is determined by the level of total savings i.e $\mathrm{S}=\mathrm{SY}$ which must be equal to net investment I.

The net investment which is $\mathrm{I}=\Delta \mathrm{K}=\mathrm{K} \Delta \mathrm{Y}$ because $\mathrm{K}$ has a direct relationship to total national income. And, therefore $\mathrm{SY}=\mathrm{K} \Delta \mathrm{Y}$ which simply means $\Delta \mathrm{Y} / \mathrm{Y}$ is growth rate of GDP that is determined by the net national savings ratio, $\mathrm{s}$ and the national capital output, $\mathrm{K}$ in the absence of government, the growth rate of national income will be positively related to the saving ratio i.e the more an economy is able to save and invest out of a given GDP, the greater the growth of GDP and which will be inversely related to capital output ratio. 
The basis of the theory is that for an economy to grow, it should be able to save and invest a certain proportion of their GDP.

\section{Stylized Facts}

Nigeria is Sub-Saharan Africa's second biggest economy, with nominal 2006 GDP of \$235bn (at PPP) 3 behind South Africa's $\$ 600 \mathrm{bn}$. It has also been one of its fastest growing economies, outpacing South Africa, Kenya, Ghana and most of its neighbors with a CAGR of 7\% over the past 10 years.

However, its growth has been more erratic due to the high reliance on natural resources (see further UNDP, Human Development Report 2007, Data for the recent year measured is 2005 and 2004 and EIU Country Profile, May 2007, Country Report, Nigeria.

3 US \$115bn was the actual GDP for 2006. below EIU expects real GDP growth to continue at a strong rate of $7.4 \%$ in 2008 and $6.5 \%$ in 2009.

This buoyant economic climate is fueling growth also in the financial sector.

FIGURE 2 - ECONOMIC GROWTH VS. NEIGHBORS

SOURCE: WDI

Despite the fast pace of growth and the strong resource endowment, Nigeria has so far not increased its GDP/capita beyond that of its smaller and resource-poor neighbors. It's GDP/capita is below that of Cameroon, Ivory Coast, Kenya, and it is only $12 \%$ that of South Africa4. Poverty and the rural nature of Nigeria puts pressure on financial services institution to innovate and to reach out to poor customers.

Composition of Economy: Nigeria's economy is heavily reliant on the oil and gas sector. It makes up more than $40 \%$ of the GDP (see "Natural Resources/Industry" in Figure 3), and accounts for virtually $100 \%$ of exports 5 and $80 \%$ of budgetary revenues for the government. Nigeria is the world's 12th largest producer of oil, mainly supplying the US. Next to natural resources the most important sector is agriculture, accounting for approximately $35 \%$ of GDP. A large portion of this is subsistence farming with declining productivity. This composition of GDP is quite unlike that of its neighbors, due to the importance of natural resources. As we will discuss in more detail below, the strong natural resources sector is one of the drivers of sophistication in the financial services industry.

While rising oil and gas prices have had a strong positive effect on GDP, exports and government revenues, it was not Nigeria's only driver of growth. For instance, in 2007 political unrest in the Delta region affected oil production, but strong growth in the non-oil sector meant that overall GDP still grew by $5.8 \%$. The non-oil sector has grown at a 7\% CAGR over the past 10 years. This growth is expected to remain robust, due to good performances in particular by communications, wholesale and retail trade, and construction. Financial sector will play a key part in facilitating further growth.

\section{Model Specification And Empirical Results}

We use Ordinary Least Square (OLS) method to examine the relationship between real GDP and other variables in our study

MODEL SPECIFICATION

In order to determine the impact of these variables on the gross capital investment, the multiple regression equation is explicitly specified in functional form as follows:

RGDP $=\mathrm{f}($ EXCRAT, EXPT, FDI, GDPCBP, IMPT, INFRAT, OPNSS $)$

Where RGDP $=$ Real Gross domestic product is dependent variable

Definition of terms

EXCRAT $=$ Exchange rate

EXPT $=$ Export

FDI $=$ Foreign Direct Investment

GDPCBP $=$ GDP at current basic price

IMPT $=$ Import

INFRAT $=$ Inflation Rate

OPNSS $=$ Openness

This can be specifically expressed in explicit econometric form as:

RGDP $=\alpha 0+\alpha 1$ EXCRAT $+\alpha 2$ EXPT $+\alpha 3$ FDI $+\alpha 4$ GDPCBP $+\alpha 5$ IMPT $+\alpha 6$ INFRAT $+\alpha 7$ OPNSS + Ut. (2)

Where $\mathrm{U}$ - stochastic or random error term (with usual properties of zero mean and non-serial correlation).

$\alpha 1-\alpha 8=\quad$ Co-efficient of associated variables

$\alpha 0=$ Constant Intercept.

Data Analysis and findings

OLS Regression Results

The Estimated Model is given below 
Foreign Trade And Economic Growth In Nigeria An Empirical Analysis

$\mathrm{RGDP}=-11089.3345776 *$ EXCRAT $+6.69316366842 * \mathrm{EXPT}+0.0490716239188 * \mathrm{FDI}-$ $1.08223193619 *$ GDPCBP $-0.0156451003621 *$ IMPT $-25860.1534204 *$ INFRAT $-88511.8918892 *$ OPNSS + 1619776.05382

Table below shows the analysis of the result of the data used in the study. The method of analysis employed is the Ordinary Least Square (OLS).

Table 1 - OLS REGRESSION ANALYSIS RESULTS

\begin{tabular}{lllll}
\hline \hline Variable & Coefficient & Std. Error & t-Statistic & Prob. \\
\hline \hline C & 1619776 & 41422.54 & -0.267713 & 0.7913 \\
EXCRAT & $-11089.33^{* *}$ & 1.939050 & 3.451775 & 0.0022 \\
EXPT & 6.693164 & 31.26640 & 0.001569 & 0.9988 \\
FDI & $0.049072 * *$ & 0.274633 & -3.940647 & 0.0007 \\
GDPCBP & -1.082232 & 0.645095 & -0.024252 & 0.9809 \\
IMPT & -0.015645 & 91827.58 & -0.281616 & 0.7808 \\
INFRAT & $-25860.15 * *$ & 26155.57 & -3.384055 & 0.0026 \\
OPNSS & -88511.89 & 4383046. & 0.369555 & 0.7151 \\
\hline \hline
\end{tabular}

R2 = 0.581731; Adj. R2 = 0.454432; F-statistics = 4.569799; Prob(F-statistic $)=0.002535 ;$ DW stat=2.487114; Source: Author's computation

Note: $* * *=$ significant at $1 \% ; * *=$ significant at $5 \%$ and $*=$ significant at $10 \%$

The result of the estimation of regression summarized in the table above shows that there is a positive relationship between Real GDP, export and foreign Direct investment. However, exchange rate, GDP at current basic price, import, inflation rate and openness are negatively related to the Real GDP. A closer look at the result shows that exchange rate, FDI and Inflation rate are statistically significant at 5 percent.

The R-squared which is the coefficient of determination, shows the percentage of variation in the dependent variable that was accounted for by variations in the explanatory variables. It measures the explanatory powers of the model. It is usually between zero and one. A close inspection of the table above indicates that the specified model has a fairly high coefficient of determination. This can be seen from Rsquared of 58 per cent. The R-squared reports that the variables can explain about 58 per cent of total variation in real gross domestic product the remaining 42 per cent variation in the real gross domestic product are not accounted for in the model or rather accounted for by other variables outside the model. The fitness of every regression result is based on its $\mathrm{R}$-squared. The adjusted $\mathrm{R}$-squared shows that asymptotically, the variables can explain approximately 45 per cent of total variation. The implication of this is that the model has goodness of fit.

F-statistics test the overall significance of the model under study. F-calculated is compared with Ftabulated where F- cal is greater than F-tab we reject the null hypothesis (Ho) and conclude that the variable is statistically significant in explaining the dependent variable. From the table, it shows that F-statistics is 4.569799; and Prob(F-statistic) is 0.002535. We, therefore, reject null hypothesis and accept alternative hypothesis. This is because it is greater than the critical values of 2.57 and 3.79 at $1 \%$ and $5 \%$ respectively. Thus, it implies that the model is statistically significantly different from zero. In other words, the explanatory variables jointly considered are significantly important in explaining variation in the dependent variable -gross domestic investment.

Durbin - Watson Statistic indicates whether there is serial correlation in the model. If there is serial correlation in model it therefore implies that the model has lost its predictive power. Durbin - Watson Statistic is given as 2.487114 and this suggests that the model is free autocorrelation. Consequently, the estimated model can be confidently relied upon for making inferences and for prediction purposes.

\subsection{Unit Root Test Result}

Literature has established that most time series variables are not stationary. Therefore, using nonstationary variables in the model might lead to spurious regression which cannot be used for precise prediction. (Gujarati, 2003). Hence, our first step is to examine the characteristics of the time series data used for estimation of the model to determine whether the variables have unit roots, that is, whether it is stationary and the order of integration. The Augmented Dickey-Fuller test is used for this purpose. A variable is considered stationary if the absolute ADF value is higher than any of the absolute Mackinnon values. The test is conducted with intercept term. 
Foreign Trade And Economic Growth In Nigeria An Empirical Analysis

Table 2: Unit Root Test Summary Statistics (Augmented Dickey Fuller)

\begin{tabular}{|l|l|l|l|l|l|}
\hline \multirow{2}{*}{ Variables } & \multicolumn{2}{|l|}{ ADF Test Statistics } & \multicolumn{2}{l|}{ Critical Values (5\%) } & $\begin{array}{l}\text { Order } \\
\text { Integration }\end{array}$ \\
\cline { 2 - 5 } & Level & 1 st Difference & Level & 1 st Difference \\
\hline EXCRAT & -0.444689 & -4.087606 & -2.963972 & -2.967767 & $\mathrm{I}(1)$ \\
\hline EXPT & 3.628358 & -3.087247 & -2.963972 & -2.967767 & $\mathrm{I}(0)$ \\
\hline FDI & -4.246195 & -6.268092 & -2.963972 & -2.971853 & $\mathrm{I}(0)$ \\
\hline GDPCBP & -3.180778 & -7.350676 & -2.963972 & -2.967767 & $\mathrm{I}(0)$ \\
\hline IMPT & -5.361801 & -9.020568 & -2.963972 & -2.967767 & $\mathrm{I}(0)$ \\
\hline INFRAT & -2.908235 & -5.102473 & -2.963972 & -2.971853 & $\mathrm{I}(1)$ \\
\hline OPNSS & 9.524677 & & -2.963972 & & $\mathrm{I}(0)$ \\
\hline RGDP & 2.328572 & 4.779310 & -2.971853 & -2.971853 & $\mathrm{I}(1)$ \\
\hline
\end{tabular}

Source: Author's computation

From the table above the results clearly shows that export, foreign direct investment, gdp at current basic price, import and degree of openness to trade are stationary at level. Meanwhile, exchange rate, inflation rate and real gross domestic product are non-stationary. This suggests the need to difference the series to obtain stationarity. At first difference, however these variables are integrated of the same order.

Cointegration test results

Co-integration analysis is carried out to determine the existence of long-run relationship that exist between the dependent variable and its regressor. When one or all of the variables is/are non-stationary at level which means they have stochastic trend. Essentially, it is used to check if the independent variables can predict the dependent variable now (short-run) or in the future (long-run). The long run relationship among the variables were examined using Johasen (1991) conitegration framework. The cointegration result is presented in table 3 below

\section{Granger Causality Test}

In order to examine the Granger causal relationships between the variables under examination we used the estimated model in the previous section. F statistic was used as a testing criterion. The results relating to the existence of Granger causal relationships between the variables are presented in table 4 below.

Table 3: Granger causality tests

\begin{tabular}{|c|c|c|c|}
\hline $\begin{array}{l}\text { Dependent } \\
\text { Variable }\end{array}$ & Testing Hypothesis & F1 & $\mathrm{F} 2$ \\
\hline \multirow{7}{*}{ RGDP } & OPNSS there is a unidirectional relationship(RGDP $\Rightarrow$ OPNSS) & 211.663 & 0.04343 \\
\hline & INFRAT there is no causality (RGDP $\neq$ INFRAT) & 0.44586 & 0.03721 \\
\hline & IMPT there is no causality (RGDP $\neq$ IMPT) & 0.40970 & 0.20980 \\
\hline & GDPCBP there is no causality (RGDP $\neq$ GDPCBP) & 1.02731 & 0.09129 \\
\hline & FDI there is no causality (RGDP $\neq \mathrm{FDI})$ & 2.14786 & 0.14565 \\
\hline & EXPT there is a unidirectional relationship (RGDP $\Rightarrow$ EXPT) & 9.11866 & 0.34629 \\
\hline & EXCRAT there is a unidirectional relationship(RGDP $\Rightarrow$ EXPT) & 3.34986 & 0.34903 \\
\hline
\end{tabular}

Source: Author's computation

From table 3 above we can infer that: there is a unidirectional causal relationship between the real gross domestic product and export with direction from real gross domestic product, unidirectional causal relationship between real gross domestic product and export with direction from real gross domestic product to export, there is a unidirectional causal relationship between the real gross domestic product and exchange rate with direction from real gross domestic product to exchange rate. Also, there is no causal relationship between the real gross domestic product and inflation rate, between real gross domestic product and import, between real gross domestic product and gdp at current basic price, and between real gross domestic product and foreign direct investment.

\subsection{SUMMARY, CONCLUSION AND RECOMMENDATION}

From this study, real GDP was used as a proxy for economic growth, which is one of the macro economic objectives. The study highlighted the pattern of export and import in Nigeria from 1970 to 2010. The study however, reviews some earliest work on it and provides some theoretical background on economic growth. Since trade favours countries that engage in it, this study also made mention of benefits accrue to 
international trade participants. It can also be inferred that Nigeria engages in international trade with other countries to stimulate the economy.

Conclusion and Recommendation: This study examined the impact of foreign trade on Economic growth in Nigeria, considering the coefficients the variables used, export and foreign direct investment are positively related to the real GDP while other variables such exchange rate, import inflation and openness rate exert a negative influence on the real GDP.

The positive coefficient of the net export ratio implies higher productivity.

The positive coefficient ratio of the foreign direct investment also helped to stimulate the economy thereby increasing capital inflow into the economy. In the light of this research, the conclusion that foreign trade exert positive effects upon Nigeria's economic growth could be drawn. Nigeria, however, is facing some serious problems such as low domestic absorptive capacity, deterioration in terms of trade, trade fiction with partners and on even development across the country. Therefore to achieve sustainable economic growth, Nigeria should pay more attention to proper and appropriate trade strategies and polices.

Recommendations: Nigeria should develop strategies to promote exports and high technical trade. This study showed that the rise in the net export volume and improvement in trade structure could improve the efficiency of Nigeria production.

A large amount of exports imply greater openness which could help domestic sectors adopt new production technology and in turn increase productivity.

Secondly, Nigeria government should strengthened the competiveness of exports by combing the imports of high technology and domestic independent research. The technological know how could be imported by direct buying or indirectly through foreign direct investment. However, the domestic absorptive ability in Nigeria is very weak. Therefore, Nigeria's government should try to import appropriate technology which can easily be absorbed and acquired by domestic firms with their corresponding capability. It is equally important to develop strong domestic sector of competitive firms that can assimilate and disseminate imported technologies and to improve their own innovative capacities.

Finally, Nigeria is government should focus on the catch up strategy by establishing a national innovation system which includes proper education, finance and industrial policy, which could promote openness and enhancing domestic absorptive capability, thereby increasing productivity of the economy.

\section{References}

[1] Akerele (2004), “Nigeria's Export Trade. Instability and Forecast” J. Development Alternatives and Area Studies. 20:61 -68.

[2] Bankole, A.S and Bankole M.A. (2004), "Industrial Trade and Export Promotion Policies and Revealed Comparative Advantage in Nigeria's Manufactured Export, in Garba.

[3] Abdul-Ganiyu et al (eds), Leading Issues in Macro Economic Management and development, NES, Ibadan.

[4] Briggs, (2007), Nigeria: Main streaming trade policy into Natural Development Strategies: African Trade Policy Centre No 52; Economic Commission for African.

[5] Egwaikhide, (1999), "Economic growth through export expansion: Evidence from Nigeria, NISER, Monograph service, No 10, NISER, Ibadan.

[6] Ekpo and Umoh, 'Growth and direction of External Trade; Google search.

[7] Ezenwe, (1979), “Nigeria and foreign trade polices in the 1980's Nigeria Journal of International Studies vol. 3, Nos 1and 2 January-June, page 94.

Fajana (1980), Trade and Growth: Nigeria Experience" World Development, vol. 7 page 73 -79

Kenea (2000): The International Economy Cambridge University press, UK.

Koutsoyiannis (1977), "Theory of Econometrics” Palgrave Houndmills, Basingstoke Macmillan press.

Lawal (1982), "A level Economics of West Africa": Heinemann Educational Books (Nig) Ltd.

Mankiw (2007) "Foreign Exchange and Economic Development". An empirical study of Latin American Vols 3-4 page 419-453.

Michealy. (1977), "Export and Economic Growth". An Empirical Investigation Journal of Development Economics, Vols 4-page 418-452.

[14] Obadan (1983), "Prospects for diversification in Nigeria's export trade in annual conference of Nigeria Economic Society", Heinemann press, Ibadan page 33-53 unpublished mass: press.

[15] Obiora (2001), "Do trading partners still matter for Nigeria's growth? A contribution to the debate on decoupling and spillovers IMF working paper.

[16] Ogbokor (2001), “Oil and Economic Growth": An Econometric Analysis' Development Alternatives and Area Studies, 20-124, Research Journal of Finance and Accounting Vol 2, No2, 2011. 